\title{
Pertumbuhan dan perkembangan anak gizi buruk masa lalu di Kabupaten Tanggamus Provinsi Lampung
}

\author{
Suhartono', Dradjat Boediman', Toto Castro ${ }^{3}$
}

\begin{abstract}
Background: Undernutrition is one of factors that influences growth and development of children and causes lost generation. In Indonesia, 2.4 million of underfives suffered from undernutrition and 7 millions of them suffered from protein energy malnutrition. In Tanggamus Regency, $46 \%$ of children suffered from protein energy malnutrition and 81 cases suffered from undernutrition.

Objective: To identify the relationship between children's previous undernutrition and their recent growth and development.

Method: The study was observational with cross sectional design. Subjects were all undernutrition cases nursed in Regional Public Hospital of Pringsewu Tanggamus from 1999-2001. Antropometric measurement was done to children's weight and height. The anthropometric indicators were weight for age z-score (waz), height for age z-score (haz), and weight for height z-score (whz). Raw motoric development was measured using Denver test. Data collected using questionnaire were child internal factors and external factors of family's characteristics and health service. One variable analysis was done descriptively, while t-test was used to know the relationship between children's previous undernutrition and their recent growth development.

Results: There was relationship between previous undernutrition of children and their recent growth $(p<0,05)$, but there was not relationship between undernutrition and their development $(p>0,05)$. The other factor that had relationship with their development were the achievement of $D / S(p<0,05)$. Factors of nutritionist, midwife, intervention, TBC's suspect, head of household education, mother education, member of family, children's parity, social status, salary, scope of $D / S$, scope of $N / D$, and scope of vitamin A tablet supplementation did not have the relationship with the growth and development of children $(p>0,05)$.

Conclusion: There was relationship between previous undernutrition of children and their recent growth, but there was not with the recent development of children. The achievement of D/S was the other factor that had relationship with the growth of children.
\end{abstract}

KEY WORDS undernutrition, growth of children, development of children, lost generation

\section{PENDAHULUAN}

Dari hasil survei sosial ekonomi nasional tahun 1998 dilaporkan bahwa terdapat 2,4 juta anak balita Indonesia menderita gizi buruk dan sejumlah 7,0 juta anak balita menderita kurang energi protein (KEP). Satu dari dua anak di Indonesia juga dilaporkan mengalami kekurangan gizi (1).

Pada tahun 1999 diperkirakan 6 juta balita berstatus gizi kurang dan 1,7 juta berstatus gizi buruk, termasuk Kabupaten Tanggamus yang sejak bulan Januari 1999 sampai Desember 2001 terjadi kejadian luar biasa (KLB) gizi atau penderita KEP berat, baik marasmus, kwashiorkor, atau marasmus kwashiorkor sebanyak 81 kasus (2).

Gizi buruk balita secara bertahap akan mempengaruhi proses pertumbuhan dan perkembangan selanjutnya. Status gizi buruk pada anak dipengaruhi oleh: kemiskinan, kesengsaraan, ketidaktahuan, kondisi kesehatan yang kurang, pelayanan kesehatan, dan stimulasi lingkungan (3).

Berkaitan dengan fenomena di atas, penulis melakukan penelitian untuk mengetahui pengaruh keadaan gizi buruk masa lalu terhadap pertumbuhan dan perkembangannya di masa sekarang. Selain itu, adanya penelitian ini diharapkan juga dapat berguna dalam mempersiapkan anak yang sehat, cerdas, produktif, serta mandiri di masa yang akan datang.

\section{BAHAN DAN METODE}

\section{Rancangan dan sampel penelitian}

Rancangan penelitian ini adalah cross sectional study dengan sampel penelitian meliputi anak balita gizi buruk masa lalu yang memenuhi kriteria inklusi dan eksklusi, sedangkan responden penelitian adalah orang tua balita. Kriteria inklusi balita meliputi: anak yang pernah menderita gizi buruk pada usia balita antara tahun 1999-2001, pernah dirawat di RSUD Pringsewu Kabupaten Tanggamus antara tahun 1999-2001,

\footnotetext{
1 Dinas Kesehatan Tanggamus, Jl. R. Suprapto Komplek Perkantoran Pemda Tanggamus Kota Agung Lampung 35384, e-mail: dinkestanggamus@depkes.go.id

2 Bagian Anak RS Dr. Sardjito, JI. Kesehatan Yogyakarta

3 Balai Pelatihan Kesehatan Salaman, Magelang Jawa Tengah
} 
berada di wilayah Kabupaten Tanggamus, dan bersedia menjadi sampel atas kesediaan orang tua. Kriteria eksklusi meliputi balita yang pernah berstatus gizi buruk dan dirawat di RSUD Pringsewu tetapi tidak lagi berdomisili di Tanggamus serta balita yang orang tuanya telah meninggal dunia.

\section{Lokasi dan waktu penelitian}

Penelitian ini dilakukan di Kabupaten Tanggamus Provinsi Lampung yang tersebar pada 15 kecamatan. Dipilihnya lokasi tersebut karena merupakan salah satu pusat informasi penanggulangan krisis kesehatan (PIPKK) di Indonesia. Waktu penelitian yaitu dari bulan September sampai dengan Desember 2002.

\section{Variabel penelitian}

Variabel bebas utama yang dipelajari adalah balita gizi buruk masa lalu dengan variabel terikat pertumbuhan dan perkembangan, sedangkan variabel pengganggu adalah faktor eksternal karakteristik keluarga (pendidikan dan pekerjaan orang tua, pendapatan, nomor urut anak, dan jumlah anggota keluarga yang ditanggung), faktor internal penyakit penyerta, dan faktor pelayanan kesehatan (tenaga gizi puskesmas, bidan desa, intervensi, dan cakupan program gizi D/S atau perbandingan antara jumlah anak yang datang dan ditimbang di posyandu terhadap seluruh anak balita yang terdaftar, N/D atau perbandingan antara jumlah anak yang naik timbangannya di posyandu terhadap seluruh anak balita yang ditimbang, vitamin $\mathrm{A}$ ).

\section{Cara pengumpulan data}

Data awal kasus gizi buruk diambil dari hasil laporan Dinas Kesehatan dan RSUD Pringsewu Kabupaten Tanggamus (rekam medis). Data tersebut selanjutnya dilacak ke puskesmas dan dicari domisili kasus pada saat ini.

Data pertumbuhan dinilai berdasarkan berat badan/umur (BB/U), tinggi badan/umur (TB/U), dan indeks berat badan/ tinggi badan ( $\mathrm{BB} / \mathrm{TB}$ ) menggunakan skala rasio. Data berat badan didapat dari hasil penimbangan dengan dacin berkapasitas $25 \mathrm{~kg}$, sedangkan data tinggi badan diperoleh dari hasil pengukuran tinggi badan dengan menggunakan pita ukur oleh peneliti langsung dibantu enumerator petugas gizi puskesmas. Data perkembangan dinilai berdasarkan kemampuan psikomotorik minimal anak berdasarkan umurnya yang diperoleh dari jawaban pengasuh atau orang tua. Perkembangan dikatakan berada dalam batas normal apabila sesuai dengan umur saat penelitian dan terhambat apabila tidak sesuai dengan umur saat penelitian. Data karakteristik keluarga diperoleh dari hasil wawancara kepada pengasuh atau orang tua dengan menggunakan kuesioner terstruktur.

\section{Analisis data}

Data diolah menggunakan program komputer SPSS dan z-score ditentukan dengan menggunakan program Nutrishof. Analisis data dilakukan menggunakan uji t untuk mengetahui hubungan keadaan gizi buruk masa lalu pada anak balita dengan pertumbuhan anak saat ini, hubungan keadaan gizi buruk masa lalu pada anak balita dengan perkembangan anak saat ini, dan hubungan faktor lain seperti faktor eksternal karakteristik keluarga (pendidikan orang tua, pekerjaan orang tua, pendapatan, nomor urut anak, dan jumlah anggota keluarga yang ditanggung), faktor internal penyakit penyerta, dan faktor pelayanan kesehatan (tenaga gizi puskesmas, bidan desa, intervensi, dan cakupan program gizi D/S , N/D dan vitamin A) dengan pertumbuhan dan perkembangan anak.

\section{HASIL}

\section{Gambaran umum wilayah penelitian}

Lokasi penelitian adalah Kabupaten Tanggamus yang memiliki wilayah $3.356,61 \mathrm{~km}^{2}$, dengan kondisi geografis yang terdiri dari daerah pegunungan dan kepulauan yang berada di Samudera Hindia serta daerah pesisir pantai.

Penduduk Kabupaten Tanggamus pada tahun 2001 berjumlah 800.211 jiwa yang tersebar pada 15 kecamatan dengan laju pertumbuhan penduduk $0,16 \%$ per tahun. Kepadatan penduduk adalah 239,07 jiwa per $\mathrm{km}^{2}$ dan ratarata 4,38 jiwa tiap rumah tangga. Pencapaian program gizi pada triwulan III tahun 2002 adalah sebagai berikut: D/S sebesar $47,9 \%$, N/D sebesar $81,0 \%$, dan KEP sebesar $46 \%$ dari 74.585 balita.

\section{Karakteristik sampel penelitian}

Pada awal penelitian, jumlah sampel yang memenuhi kriteria inklusi adalah 81 orang. Di antara jumlah tersebut, 43 sampel drop out karena meninggal dunia, pindah, dan orang tuanya meninggal dunia, sehingga sampel penelitian ini berjumlah 38 orang (Gambar 1).

Umur rata-rata balita kasus gizi buruk saat ditemukan adalah 16,68 $\pm 12,42$ bulan. Pada umur ini, sampel rentan mengalami kasus gizi buruk. Penderita kasus gizi buruk dengan diagnosis marasmus berjumlah 31 orang $(81,6 \%)$ dan merupakan kasus gizi buruk terbanyak di Kabupaten Tanggamus, sedangkan diagnosis kwashiorkor ditemukan berjumlah 7 orang $(18,4 \%)$. Diagnosis ditentukan oleh dokter spesialis anak di Rumah Sakit Pringsewu. Ratarata z-score kasus gizi buruk adalah $-4,299 \pm 0,886 \mathrm{SD}$. Dari kasus tersebut, yang menjadi sampel disertai dengan penyakit TBC sebanyak $26(68,4 \%)$ kasus dan $12(31,6 \%)$ kasus tanpa penyakit penyerta. 


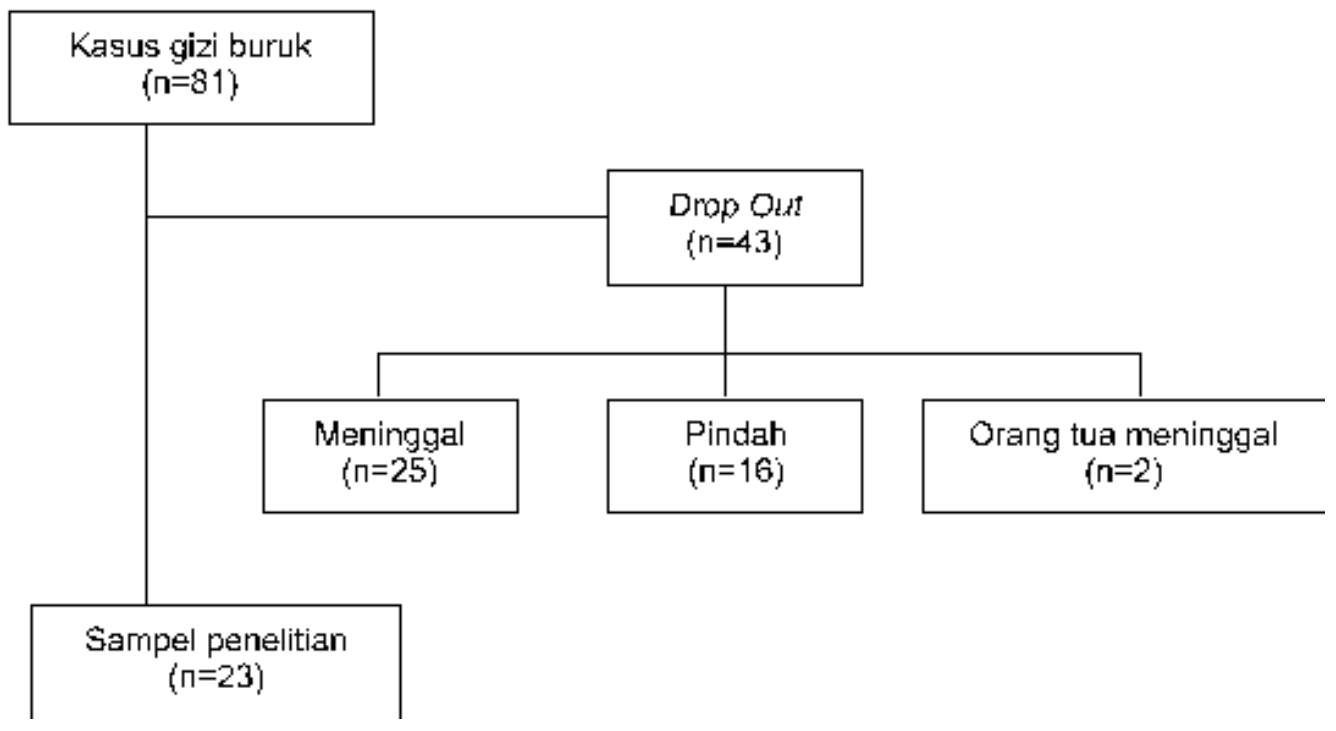

Gambar 1. Profil Penelitian

Hubungan status gizi buruk masa lalu dengan pertumbuhan anak saat ini

Hasil analisis uji t antara status gizi masa lalu dengan pertumbuhan anak saat ini diperoleh nilai $p<0,05$ yang menunjukkan ada perbedaan signifikan antara z-score status gizi masa lalu dengan nilai z-score status gizi saat ini. Dengan demikian dapat diketahui bahwa status gizi buruk masa lalu berhubungan dengan pertumbuhan anak saat ini (Tabel 1).

\section{Hubungan status gizi buruk masa lalu dengan perkembangan anak saat ini}

Hasil penelitian ini menunjukkan masih ada $13(34,2 \%)$ anak yang terhambat perkembangan motorik kasar minimal pada usia yang seharusnya. Perkembangan anak dapat dikatakan masih berada dalam batas ambang normal (BAN) apabila kemampuan motorik anak sesuai dengan usianya

TABEL 1. Hubungan status gizi masa lalu dengan pertumbuhan anak saat ini

\begin{tabular}{lccc}
\hline \multicolumn{1}{c}{ Status gizi } & \multicolumn{2}{c}{ MeantSD } & \multicolumn{2}{c}{ Statistik } \\
& (z-score) & t & p \\
\hline Masa lalu & $-4,299 \pm 0,886$ & $-7,43$ & $0,000^{*}$ \\
Saat ini & $-2,63 \pm 1,065$ & & \\
\hline
\end{tabular}

Keterangan:

* Signifikan $(p<0,05)$ yang diketahui melalui wawancara dengan orang tua atau pengasuh. Hasil uji statistik menggunakan uji $t$ menunjukkan nilai $p>0,05$ yang dapat dikatakan bahwa tidak ada hubungan yang signifikan antara status gizi buruk masa lalu dengan perkembangan anak saat ini (Tabel 2).

Dilihat dari hubungan antara pertumbuhan dan perkembangan anak saat ini, hasilnya menunjukkan bahwa sebanyak $5(13,5 \%)$ anak yang berstatus gizi kurang dan 6 $(15,8 \%)$ anak yang berstatus gizi buruk terhambat perkembangannya. Hasil uji statistik dengan uji t didapatkan hasil yang tidak signifikan ( $p>0,05)$ (Tabel 3 ).

\section{Hubungan faktor lain dengan pertumbuhan anak saat ini}

Faktor eksternal karakteristik keluarga Orang tua balita yang berstatus gizi kurang dan buruk sebagian besar memiliki tingkat pendidikan akhir sekolah dasar, sedangkan pekerjaan ayahnya sebagian besar adalah petani (buruh tani) masing-masing sebanyak 23,7 dan ibu tidak bekerja masing-masing sebanyak $28,9 \%$ dan $18,4 \%$.

Jumlah anggota keluarga anak dengan status gizi kurang dan gizi buruk sebagian besar lebih dari 4 (empat) orang yaitu sebanyak $44,7 \%$ untuk anak dengan status gizi kurang dan sebanyak $28,9 \%$ untuk anak dengan status gizi buruk. Selain itu, pada umumnya merupakan anak

TABEL 2. Hubungan status gizi masa lalu dengan perkembangan anak saat ini

\begin{tabular}{|c|c|c|c|c|c|}
\hline \multirow{2}{*}{ Perkembangan } & \multirow{2}{*}{$\mathbf{n}$} & \multirow[t]{2}{*}{$\%$} & Z-score & \multicolumn{2}{|c|}{ Statistik } \\
\hline & & & MeantSD & $\mathbf{t}$ & $\mathbf{p}$ \\
\hline Batas ambang normal ( $\mathrm{BAN}$ ) & 25 & 65,8 & $-4,28 \pm 0,85$ & $-0,184$ & 0,85 \\
\hline Terhambat & 13 & 34,2 & $-4,34 \pm 0,99$ & & \\
\hline
\end{tabular}


TABEL 3. Hubungan status gizi saat ini dengan perkembangan anak saat ini

\begin{tabular}{|c|c|c|c|c|c|c|c|c|c|c|}
\hline \multirow{3}{*}{ Perkembangan } & \multicolumn{6}{|c|}{ Pertumbuhan } & \multirow{2}{*}{\multicolumn{2}{|c|}{ Total }} & \multirow{3}{*}{$\mathbf{t}$} & \multirow{3}{*}{$\mathbf{p}$} \\
\hline & \multicolumn{2}{|c|}{ Gizi baik } & \multicolumn{2}{|c|}{ Gizi kurang } & \multicolumn{2}{|c|}{ Gizi buruk } & & & & \\
\hline & $\mathbf{n}$ & $\%$ & $\mathbf{n}$ & $\%$ & $\mathbf{n}$ & $\%$ & $\mathbf{n}$ & $\%$ & & \\
\hline Batas ambang normal (BAN) & 5 & 13,2 & 13 & 34,2 & 7 & 18,4 & 25 & 65,8 & 0,906 & 0,374 \\
\hline Terhambat & 2 & 5,3 & 5 & 13,5 & 6 & 15,8 & 13 & 34,2 & & \\
\hline
\end{tabular}

nomor urut lebih dari yang kedua, yaitu sebanyak 39,5\% untuk anak dengan status gizi kurang dan sebanyak $26,3 \%$ untuk anak dengan status gizi buruk.

Status sosial anak, baik dengan status gizi baik, gizi kurang, maupun gizi buruk tergolong keluarga prasejahtera sebanyak 34 kasus dengan penghasilan di bawah upah minimum provinsi/UMP sebesar Rp 450.000,- (kategori kurang) untuk anak dengan status gizi kurang dan gizi buruk masingmasing sebanyak $15(39,5 \%)$ dan 11 (28,9\%) kepala keluarga.

Dari hasil analisis hubungan antara faktor eksternal karakteristik keluarga dengan pertumbuhan (status gizi), tidak terbukti adanya faktor yang berhubungan dengan pertumbuhan anak saat ini (Tabel 4).

Faktor internal penyakit penyerta Kasus gizi buruk masa lalu yang disertai penyakit TBC lebih banyak daripada yang tidak disertai penyakit TBC. Sebanyak $14(36,8 \%)$ anak dengan status gizi kurang dan $7(18,4 \%)$ anak dengan status gizi buruk diketahui pernah menderita penyakit TBC.
Hasil uji t menunjukan tidak ada hubungan antara penyakit penyerta TBC pada masa lalu dengan pertumbuhan anak saat ini $(p>0,05)$ (Tabel 5).

Faktor pelayanan kesehatan Sebagian besar anak dengan status gizi kurang dan gizi buruk mendapatkan pelayanan gizi dari petugas pelaksana gizi yang berasal dari tenaga pembantu ahli gizi/SPAG atau ahli gizi/AKZI, namun $26,3 \%$ wilayah tempat tinggal anak dengan status gizi kurang dan $18,4 \%$ anak dengan status gizi buruk tidak memiliki tenaga bidan di desa.

Sebanyak $11(28,9 \%)$ keluarga anak dengan status gizi kurang memperoleh intervensi dalam bentuk pemberian makanan tambahan (PMT) pemulihan ditambah dana bantuan pemberdayaan keluarga dan hanya $4(10,5 \%)$ keluarga anak dengan status gizi baik yang memperoleh intervensi dan dana yang sama. Selain itu, sebanyak $23,7 \%$ wilayah masing-masing tempat tinggal anak dengan status gizi kurang dan gizi buruk memiliki hasil pelayanan

TABEL 4. Hubungan faktor eksternal karateristik keluarga dengan pertumbuhan anak saat ini menggunakan indikator berat badan/umur (BB/U)

\begin{tabular}{|c|c|c|c|c|c|c|c|c|c|c|}
\hline \multirow{3}{*}{ Faktor lain } & \multicolumn{6}{|c|}{ Pertumbuhan } & \multirow{2}{*}{\multicolumn{2}{|c|}{ Total }} & \multirow{3}{*}{$\mathbf{t}$} & \multirow{3}{*}{$\mathbf{p}$} \\
\hline & \multicolumn{2}{|c|}{ Gizi baik } & \multicolumn{2}{|c|}{ Gizi kurang } & \multicolumn{2}{|c|}{ Gizi buruk } & & & & \\
\hline & $\mathbf{n}$ & $\%$ & $\mathbf{n}$ & $\%$ & $\mathbf{n}$ & $\%$ & $\mathbf{n}$ & $\%$ & & \\
\hline Pendidikan ayah & & & & & & & & & & \\
\hline Sekolah dasar & 6 & 15,8 & 15 & 39,5 & 10 & 26,3 & 31 & 81,6 & $-0,5$ & 0,63 \\
\hline Sekolah menengah & 1 & 2,6 & 3 & 7,9 & 3 & 7,9 & 7 & 18,4 & & \\
\hline Pendidikan ibu & & & & & & & & & & \\
\hline Sekolah dasar & 6 & 15,8 & 17 & 44,7 & 11 & 28,9 & 34 & 89,5 & $-0,21$ & 0,84 \\
\hline Sekolah menengah & 1 & 2,6 & 1 & 2,6 & 2 & 5,3 & 4 & 10,5 & & \\
\hline Pekerjaan ayah & & & & & & & & & & \\
\hline Ojek & 0 & 0 & 6 & 15,8 & 2 & 5,3 & 8 & 21,1 & $-0,12$ & 0,94 \\
\hline Tani & 6 & 15,8 & 9 & 23,7 & 9 & 23,7 & 24 & 63,2 & & \\
\hline Wiraswasta & 1 & 2,6 & 3 & 7,9 & 2 & 5,3 & 6 & 15,8 & & \\
\hline Pekerjaan ibu & & & & & & & & & & \\
\hline Tidak bekerja & 5 & 13,2 & 11 & 28,9 & 7 & 18,4 & 23 & 60,5 & $-0,75$ & 0,45 \\
\hline Bekerja & 2 & 5,3 & 7 & 18,4 & 6 & 15,8 & 15 & 39,5 & & \\
\hline Jumlah anggota keluarga & & & & & & & & & & \\
\hline$\leq 4$ & 0 & 0 & 1 & 2,6 & 2 & 5,3 & 3 & 7,9 & 1,56 & 0,23 \\
\hline$>4$ & 7 & 18,4 & 17 & 44,7 & 11 & 28,9 & 35 & 92,1 & & \\
\hline Nomor urut anak & & & & & & & & & & \\
\hline$>2$ & 6 & 15,8 & 15 & 39,5 & 10 & 26,3 & 31 & 81,6 & 0,78 & 0,63 \\
\hline$\leq 2$ & 1 & 2,6 & 3 & 7,9 & 3 & 7,9 & 7 & 18,4 & & \\
\hline Status sosial & & & & & & & & & & \\
\hline Sejahtera & 1 & 2,6 & 0 & 0 & 3 & 7,9 & 4 & 10,5 & 0,77 & 0,51 \\
\hline Prasejahtera & 6 & 15,8 & 18 & 47,4 & 10 & 26,3 & 34 & 89,5 & & \\
\hline Penghasilan & & & & & & & & & & \\
\hline Cukup $(\geq \operatorname{Rp} 450.000,-)$ & 1 & 2,6 & 3 & 7,9 & 2 & 5,3 & 6 & 15,8 & 0,32 & 0,98 \\
\hline Kurang $(<\operatorname{Rp} 450.000,-)$ & 6 & 15,8 & 15 & 39,5 & 11 & 28,9 & 32 & 84,2 & & \\
\hline
\end{tabular}


TABEL 5. Hubungan faktor internal penyakit penyerta dengan pertumbuhan anak saat ini menggunakan indikator berat badan/umur (BB/U)

\begin{tabular}{|c|c|c|c|c|c|c|c|c|c|c|}
\hline \multirow{3}{*}{ Faktor internal penyakit penyerta } & \multicolumn{6}{|c|}{ Pertumbuhan } & \multirow{2}{*}{\multicolumn{2}{|c|}{ Total }} & \multirow{3}{*}{$\mathbf{t}$} & \multirow{3}{*}{$\mathbf{p}$} \\
\hline & \multicolumn{2}{|c|}{ Gizi baik } & \multicolumn{2}{|c|}{ Gizi kurang } & \multicolumn{2}{|c|}{ Gizi buruk } & & & & \\
\hline & $\mathbf{n}$ & $\%$ & $\mathbf{n}$ & $\%$ & $\mathbf{n}$ & $\%$ & $\mathbf{n}$ & $\%$ & & \\
\hline Penyakit kronis & & & & & & & & & & \\
\hline TBC & 5 & 13,2 & 14 & $\begin{array}{l}36,8 \\
105\end{array}$ & 7 & $\begin{array}{l}18,4 \\
158\end{array}$ & $\begin{array}{l}26 \\
12\end{array}$ & $\begin{array}{l}68,4 \\
31\end{array}$ & $-0,98$ & 0,34 \\
\hline
\end{tabular}

kesehatan cakupan persen $\mathrm{D} / \mathrm{S}<80 \%$, sedangkan cakupan persentase N/D $>80 \%$ pada wilayah anak dengan status gizi baik hanya sebanyak $3(7,9 \%)$ wilayah. Sementara itu, faktor pelayanan kesehatan hasil distribusi vitamin A pada wilayah anak dengan status gizi baik hanya terdapat pada 1 wilayah yang cakupannya lebih dari $80 \%$.

Hasil uji statistik menunjukkan tidak satu pun faktor pelayanan kesehatan yang berhubungan dengan pertumbuhan anak saat ini $(p>0,05)$ Untuk mengetahui hubungan pelayanan kesehatan dengan pertumbuhan anak dengan status gizi baik, kurang, dan buruk secara lebih rinci dapat dilihat pada Tabel 6.

\section{Hubungan faktor lain dengan perkembangan anak saat ini}

Faktor eksternal karakteristik keluarga Pada penelitian ini, terdapat 25 kasus anak dengan perkembangan BAN. Pendidikan orang tua sampai sekolah menengah dari anak yang perkembangannya terhambat jumlahnya sangat sedikit yaitu sebanyak $2(5,3 \%)$ kasus. Pekerjaan ayah yang terbanyak sebagai buruh tani, baik pada anak yang perkembangannya terhambat maupun yang melampaui BAN, sedangkan perkembangan anak pada ibu yang tidak bekerja sebagian besar melampaui BAN yaitu sebanyak $17(44,7 \%)$ anak.

Anak yang perkembangannya melampaui BAN dan yang terhambat ditemukan pada keluarga yang memiliki jumlah anggota keluarga lebih dari 4 orang dan sebagian merupakan anak dengan nomor urut lebih dari kedua. Status sosial keluarga anak dengan perkembangan terhambat dan melampaui BAN sebagian termasuk kategori prasejahtera atau keluarga kurang mampu dengan penghasilan kurang dari UMP yaitu sebesar Rp 450.000,--

Hasil uji t dari semua faktor eksternal karakteristik keluarga tidak ditemukan adanya hubungan yang signifikan dengan perkembangan anak ( $p>0,05)$ (Tabel 7).

Faktor internal penyakit penyerta Hasil uji stastistik antara perkembangan anak dengan penyakit penyerta TBC masa lalu menunjukkan hubungan yang tidak signifikan dengan $p>0,05$ (Tabel 8).

Faktor pelayanan kesehatan Dalam bidang pelayanan kesehatan dapat diketahui bahwa petugas gizi yang merupakan salah satu dari faktor pelayanan kesehatan bukan

TABEL 6. Hubungan faktor pelayanan kesehatan dengan pertumbuhan menggunakan indikator berat badan/umur (BB/U)

\begin{tabular}{|c|c|c|c|c|c|c|c|c|c|c|}
\hline \multirow{3}{*}{ Faktor pelayanan kesehatan } & \multicolumn{6}{|c|}{ Pertumbuhan } & \multirow{2}{*}{\multicolumn{2}{|c|}{ Total }} & \multirow{3}{*}{$\mathbf{t}$} & \multirow{3}{*}{$\mathbf{p}$} \\
\hline & \multicolumn{2}{|c|}{ Gizi baik } & \multicolumn{2}{|c|}{ Gizi kurang } & \multicolumn{2}{|c|}{ Gizi buruk } & & & & \\
\hline & $\mathbf{n}$ & $\%$ & $\mathbf{n}$ & $\%$ & $\mathbf{n}$ & $\%$ & $\mathbf{n}$ & $\%$ & & \\
\hline \multicolumn{11}{|l|}{ Petugas gizi } \\
\hline Gizi & 5 & 13,2 & 10 & 26,3 & 10 & 26,3 & 25 & 65,8 & \multirow[t]{2}{*}{0,53} & \multirow[t]{2}{*}{0,603} \\
\hline Bukan gizi & 2 & 5,3 & 8 & 21,1 & 3 & 7,9 & 13 & 34,2 & & \\
\hline \multicolumn{11}{|l|}{ Bidan desa } \\
\hline Ada bidan desa & 4 & 10,5 & 8 & 21,1 & 6 & 21,1 & 18 & 47,4 & \multirow[t]{3}{*}{$-0,37$} & \multirow[t]{2}{*}{0,71} \\
\hline Tidak ada bidan desa & 3 & 7,9 & 10 & 26,3 & 7 & 18,4 & 20 & 52,6 & & \\
\hline \multicolumn{10}{|l|}{ Intervensi } & \\
\hline PMT+Rp 1.000.000,- & 4 & 10,5 & 11 & 28,9 & 3 & 7,9 & 18 & 47,4 & \multirow[t]{2}{*}{$-1,81$} & \multirow[t]{2}{*}{0,76} \\
\hline PMT & 3 & 7,9 & 7 & 18,4 & 10 & 26,3 & 20 & 52,6 & & \\
\hline \multicolumn{11}{|l|}{ Persen D/S } \\
\hline Baik & 2 & 5,3 & 9 & 23,7 & 4 & 10,5 & 15 & 39,5 & \multirow[t]{2}{*}{$-0,18$} & \multirow[t]{2}{*}{0,86} \\
\hline Kurang & 5 & 13,2 & 9 & 23,7 & 9 & 23,7 & 23 & 60,5 & & \\
\hline \multicolumn{11}{|l|}{ Persen N/D } \\
\hline Baik & 3 & 7,9 & 14 & 36,8 & 7 & 18,4 & 24 & 63,2 & \multirow[t]{2}{*}{0,90} & \multirow[t]{2}{*}{0,93} \\
\hline Kurang & 4 & 10,5 & 4 & 10,5 & 6 & 21,1 & 14 & 36,8 & & \\
\hline \multicolumn{11}{|l|}{ Cakupan vitamin A } \\
\hline Baik & 1 & 2,6 & 11 & 28,9 & 6 & 21,1 & 18 & 47,4 & \multirow[t]{2}{*}{0,99} & \multirow[t]{2}{*}{0,33} \\
\hline Kurang & 6 & 15,8 & 7 & 18,4 & 7 & 18,4 & 20 & 52,6 & & \\
\hline
\end{tabular}


TABEL 7. Hubungan faktor eksternal karateristik keluarga dengan perkembangan anak saat ini

\begin{tabular}{|c|c|c|c|c|c|c|c|c|}
\hline \multirow{3}{*}{ Faktor lain } & \multicolumn{4}{|c|}{$\begin{array}{r}\text { Perkembangan } \\
\end{array}$} & \multirow{2}{*}{\multicolumn{2}{|c|}{ Total }} & \multirow{3}{*}{$\mathbf{t}$} & \multirow{3}{*}{$\mathbf{p}$} \\
\hline & \multicolumn{2}{|c|}{$\begin{array}{c}\text { Batas ambang normal } \\
\text { (BAN) }\end{array}$} & \multicolumn{2}{|c|}{ Terhambat } & & & & \\
\hline & $\mathbf{n}$ & $\%$ & $n$ & $\%$ & $\mathrm{n}$ & $\%$ & & \\
\hline \multicolumn{9}{|l|}{ Pendidikan ayah } \\
\hline Sekolah dasar & 20 & 52,6 & 11 & 28,9 & 31 & 81,6 & 0,34 & 0,73 \\
\hline Sekolah menengah & 5 & 13,2 & 2 & 65,3 & 7 & 18,4 & & \\
\hline \multicolumn{9}{|l|}{ Pendidikan ibu } \\
\hline Sekolah dasar & 21 & 55,3 & 13 & 34,2 & 34 & 89,5 & 1,53 & 0,13 \\
\hline Sekolah menengah & 4 & 10,5 & 0 & 0 & 4 & 10,5 & & \\
\hline \multicolumn{9}{|l|}{ Pekerjaan ayah } \\
\hline Ojek & 7 & 18,4 & 1 & 2,6 & 8 & 21,1 & $-1,03$ & 0,31 \\
\hline Tani & 14 & 36,8 & 10 & 26,3 & 24 & 63,2 & & \\
\hline Wiraswasta & 4 & 10,5 & 2 & 5,3 & 6 & 15,8 & & \\
\hline \multicolumn{9}{|l|}{ Pekerjaan ibu } \\
\hline Tidak bekerja & 17 & 44,7 & 6 & 15,8 & 23 & 60,5 & $-1,26$ & 0,22 \\
\hline Bekerja & 8 & 21,1 & 7 & 18,4 & 15 & 39,5 & & \\
\hline \multicolumn{9}{|l|}{ Jumlah anggota keluarga } \\
\hline$\leq 4$ & 1 & 2,6 & 2 & 5,3 & 3 & 7,9 & 1,22 & 0,228 \\
\hline$\overline{>4}$ & 24 & 63,2 & 11 & 28,9 & 35 & 92,1 & & \\
\hline \multicolumn{9}{|l|}{ Nomor urut anak } \\
\hline$>2$ & 21 & 55,3 & 10 & 26,3 & 31 & 81,6 & 0,78 & 0,443 \\
\hline$\leq 2$ & 4 & 10,5 & 3 & 7,9 & 7 & 18,4 & & \\
\hline \multicolumn{9}{|l|}{ Status sosial } \\
\hline Sejahtera & 1 & 2,6 & 3 & 7,9 & 4 & 10,5 & 1,85 & 0,072 \\
\hline Prasejahtera & 24 & 63,2 & 10 & 26,3 & 34 & 89,5 & & \\
\hline \multicolumn{9}{|l|}{ Penghasilan } \\
\hline Cukup ( $\geq \operatorname{Rp} 450.000,-)$ & 4 & 10,5 & 2 & 5,3 & 6 & 15,8 & 0,048 & 0,962 \\
\hline Kurang (<Rp 450.000,-) & 21 & 55,3 & 11 & 28,9 & 32 & 84,2 & & \\
\hline
\end{tabular}

TABEL 8. Hubungan faktor internal penyakit penyerta dengan perkembangan anak saat ini

\begin{tabular}{|c|c|c|c|c|c|c|c|c|}
\hline \multirow{3}{*}{$\begin{array}{c}\text { Faktor internal penyakit } \\
\text { penyerta }\end{array}$} & \multicolumn{4}{|c|}{ Perkembangan } & & & \multirow{3}{*}{$\mathbf{t}$} & \multirow{3}{*}{$\mathbf{p}$} \\
\hline & \multicolumn{2}{|c|}{$\begin{array}{c}\text { Batas ambang normal } \\
\text { (BAN) }\end{array}$} & \multicolumn{2}{|c|}{ Terhambat } & \multicolumn{2}{|c|}{ Total } & & \\
\hline & $n$ & $\%$ & $\mathbf{n}$ & $\%$ & $\mathbf{n}$ & $\%$ & & \\
\hline \multicolumn{9}{|l|}{ Penyakit kronis } \\
\hline TBC & 17 & 44,7 & 9 & 23,7 & 26 & 68,4 & 0,75 & 0,941 \\
\hline Tidak TBC & 8 & 21,1 & 4 & 10,5 & 12 & 31,6 & & \\
\hline
\end{tabular}

merupakan faktor yang berhubungan dengan perkembangan anak saat ini $(p>0,05)$. Demikian juga pelayanan kesehatan dari tenaga bidan di desa tidak mempunyai hubungan dengan perkembangan anak saat ini $(p>0,05)$.

Selain itu, hanya intervensi PMT yang diperoleh oleh sebagian besar kasus gizi buruk yang dijadikan subjek dalam penelitian ini. Hasil uji statistik menunjukan tidak ada perbedaan signifikan pada anak yang mendapat intervensi PMT ditambah dana Rp 1.000.000,- dengan anak yang hanya mendapat PMT saja $(p>0,05)$, sehingga intervensi bukan merupakan faktor yang berhubungan dengan perkembangan. Sementara itu, pencapaian cakupan persen D/S yang merupakan partisipasi masyarakat untuk datang ke penimbangan di posyandu menunjukkan hubungan yang signifikan dengan perkembangan anak dengan nilai $p<0,05$ (Tabel 9).

\section{BAHASAN}

Hubungan status gizi buruk masa lalu dengan pertumbuhan anak saat ini

Pada penelitian ini diketahui adanya hubungan yang signifikan antara status gizi buruk masa lalu dengan pertumbuhan anak saat ini (Tabel 1). Menurut Soetjiningsih dkk. (3), malnutrisi secara lambat akan mempengaruhi pertumbuhan atau kualitas fisik anak di masa yang akan datang.

Hubungan status gizi buruk masa lalu dengan perkembangan anak saat ini

Dari hasil penelitian ini ditemukan 13 (34,2\%) anak yang memiliki perkembangan tidak normal dan hasil uji statistik menunjukkan tidak ada hubungan yang signifikan 
antara status gizi masa lalu dengan perkembangan anak saat ini $(p>0,05)$. Walaupun secara statistik hubungan tersebut tidak signifikan, keadaan gizi buruk di masa lalu akan berdampak pada gangguan organ tubuh seperti: cacat pada tangan, kaki, bahkan perkembangan mental. Gangguan yang ditimbulkan tersebut ada yang bersifat permanen dari beberapa subjek yang ditemukan. Dilaporkan oleh Satoto (4) dan Suandi (5) bahwa ada hubungan antara status gizi masa lalu dengan perkembangan anak pada masa yang akan datang. Bahkan, hasil penelitian Soetjiningsih dkk. (3) menunjukkan ada perbedaan yang signifikan antara anak yang malnutrisi dan normal pada perkembangan sosialnya.

\section{Hubungan faktor lain dengan pertumbuhan dan perkembangan anak saat ini}

Pada penelitian ini tidak ditemukan hubungan antara variabel karakteristik kasus, keluarga, dan pelayanan kesehatan dengan pertumbuhan/status gizi. Hal ini dapat disebabkan oleh faktor lain yang diteliti merupakan faktor yang tidak langsung berhubungan dengan status gizi. Menurut penelitian Satoto (4), kesakitan merupakan salah satu faktor yang berhubungan dengan status gizi, demikian juga menurut laporan Unicef tahun 1998 bahwa penyakit infeksi merupakan faktor penyebab langsung kekurangan gizi pada anak. Prawirohartono (6) dalam penelitiannya juga membuktikan bahwa faktor-faktor yang mempengaruhi status gizi secara tidak langsung antara lain: ekonomi, pertanian, pendidikan, pekerjaan, lingkungan, dan pelayanan kesehatan, sedangkan faktor langsung yang mempengaruhi status gizi adalah asupan zat gizi dan penyakit.

Selain faktor-faktor di atas, pencapaian program gizi yang dilihat dari nilai $D / S$ juga menunjukkan adanya hubungan yang signifikan dengan perkembangan anak saat ini $(p<0,05)$. Hasil penelitian Widayani dkk. (7) membuktikan adanya hubungan yang signifikan antara pola asuh kesehatan dan status gizi balita. Salah satu pola asuh kesehatan yang dinilai pada penelitian tersebut adalah penimbangan di posyandu (D/S). Dengan adanya kunjungan ke posyandu, diharapkan pertumbuhan dan perkembangan anak dapat dipantau sedini mungkin. Selain itu, ada interaksi anak dengan lingkungan pada saat pelaksanaan posyandu (Tabel 9).

Faktor psikososial berpengaruh pada tumbuh-kembang anak, termasuk stimulasi, motivasi kelompok sebaya, serta kualitas interaksi antara anak dengan lingkungan (8). Dalam hal ini, posyandu merupakan tempat anak mendapatkan semua faktor psikososial tersebut, terlebih lagi dalam kegiatan bina keluarga balita. Namun demikian, bukan lamanya interaksi yang berpengaruh terhadap tumbuhkembang anak, melainkan kualitas yang berarti bahwa posyandu merupakan tempat pelayanan kesehatan dan terdapatnya tenaga kesehatan bidan, petugas gizi, bahkan terkadang dokter yang akan memberikan pelayanan pada anak di posyandu, sehingga kualitas interaksi anak dapat dipastikan akan baik.

Dari hasil penelitian ini, terlihat bahwa upaya rehabilitasi untuk memulihkan kasus yang pernah mengalami gizi buruk kurang optimal. Hal ini terlihat dari adanya 4 kasus yang

TABEL 9. Hubungan faktor pelayanan kesehatan dengan perkembangan anak saat ini

\begin{tabular}{|c|c|c|c|c|c|c|c|c|}
\hline \multirow{3}{*}{ Faktor pelayanan kesehatan } & \multicolumn{4}{|c|}{ Perkembangan } & \multirow{2}{*}{\multicolumn{2}{|c|}{ Total }} & \multirow{3}{*}{$\mathbf{t}$} & \multirow{3}{*}{$\mathbf{p}$} \\
\hline & \multicolumn{2}{|c|}{$\begin{array}{l}\text { Batas ambang normal } \\
\text { (BAN) }\end{array}$} & \multicolumn{2}{|c|}{ Terhambat } & & & & \\
\hline & $\mathbf{n}$ & $\%$ & $\mathbf{n}$ & $\%$ & $\mathbf{n}$ & $\%$ & & \\
\hline \multicolumn{9}{|l|}{ Petugas gizi } \\
\hline Gizi & 18 & 47,4 & 7 & 18,4 & 25 & 65,8 & $-1,06$ & 0,29 \\
\hline Bukan gizi & 7 & 18,4 & 6 & 15,8 & 13 & 34,2 & & \\
\hline \multicolumn{9}{|l|}{ Bidan desa } \\
\hline Ada bidan desa & 12 & 31,6 & 6 & 15,8 & 18 & 47,4 & $-0,10$ & 0,91 \\
\hline Tidak ada bidan desa & 13 & 34,2 & 7 & 18,4 & 20 & 52,6 & & \\
\hline \multicolumn{9}{|l|}{ Intervensi } \\
\hline PMT + Rp 1.000.000,- & 13 & 34,2 & 5 & 13,2 & 18 & 47,4 & 0,78 & 0,443 \\
\hline PMT & 12 & 31,6 & 8 & 21,1 & 20 & 52,6 & & \\
\hline \multicolumn{9}{|l|}{ Persen D/S } \\
\hline Baik & 7 & 18,4 & 8 & 21,1 & 15 & 39,5 & 2,06 & $0,046^{*}$ \\
\hline Kurang & 18 & 47,4 & 5 & 13,2 & 23 & 60,5 & & \\
\hline \multicolumn{9}{|l|}{ Persen N/D } \\
\hline Baik & 17 & 44,7 & 7 & 18,4 & 24 & 63,2 & 0,82 & 0,41 \\
\hline Kurang & 8 & 21,1 & 6 & 15,8 & 14 & 36,8 & & \\
\hline \multicolumn{9}{|l|}{ Cakupan vitamin A } \\
\hline Baik & 10 & 26,3 & 8 & 21,1 & 18 & 47,4 & 1,24 & 0,22 \\
\hline Kurang & 15 & 39,5 & 5 & 13,2 & 20 & 52,6 & & \\
\hline
\end{tabular}

Keterangan:

* Signifikan $(p<0,05)$ 
meninggal pada saat perawatan di rumah sakit dan 21 kasus meninggal setelah dinyatakan sembuh. Suatu analisis terpadu (analisis meta) 8 penelitian dari 5 negara berkembang (Bangladesh, India, Malawi, Tanzania, dan Papua Nugini) menunjukan adanya hubungan yang kuat antara KEP dan kematian anak (9). Menurut WHO, faktor gizi memberikan kontribusi sangat signifikan pada penyebab kematian yaitu mencapai 54 persen (10).

Dari semua peristiwa yang ditemukan pada penelitian ini, dapat diketahui bahwa status gizi buruk masa lalu dapat menyebabkan kematian dan gangguan perkembangan anak, sehingga dapat dikatakan sebagai kejadian generasi yang hilang atau lost generation. Dengan demikian, usia yang terus bertambah tidak mempengaruhi pertumbuhan dan perkembangan anak atau terhambat, bahkan membekas atau cacat permanen.

\section{KESIMPULAN DAN SARAN}

Status gizi buruk di masa lalu berhubungan dengan pertumbuhan anak saat ini, namun tidak berhubungan dengan perkembangan anak saat ini. Pertumbuhan dan perkembangan anak saat ini juga tidak berhubungan dengan faktor lain dari faktor eksternal karakteristik keluarga, faktor internal penyakit penyerta, dan faktor pelayanan kesehatan, namun pencapaian D/S (partisipasi

\section{RUJUKAN}

1. Yulfita. Dampak Krisis Moneter terhadap Pertumbuhan Anak Indonesia: Seandainya Aku Bukan Anakmu (Potret Kehidupan Anak Indonesia). Kompas 2000. p. 8-19.

2. Mudapati. Penanggulangan Kasus Gizi Buruk di Rumah Sakit Pringsewu. Lampung: RSUD Pringsewu; 2002.

3. Soetjiningsih, Nurhayati, Suandi IKD. Tingkat Kematangan Sosial pada Anak Malnutrisi. Dalam: Kanwil Kesehatan Provinsi Bali, editor. Kumpulan Makalah Ceramah IImiah Upaya Antisipasi Masalah Gizi Anak pada Masa Krismon. Denpasar: Kanwil Kesehatan Provinsi Bali; 1998.

4. Satoto. Pertumbuhan dan Perkembangan Anak (Pengamatan anak Umur $\geq 18$ Bulan di Kecamatan Mlonggo, Kabupaten Jepara, Jawa Tengah) [disertasi]. Semarang: Universitas Diponegoro;1990. masyarakat) menunjukkan adanya hubungan signifikan dengan perkembangan anak saat ini.

Berdasarkan kesimpulan di atas, beberapa saran yang dapat digunakan untuk mencegah terjadinya kasus gizi buruk sedini mungkin antara lain: revitalisasi posyandu guna peningkatan cakupan D/S dan N/D yang diharapkan dapat menurunkan risiko gizi buruk dengan pemantauan pertumbuhan dan perkembangan anak sedini mungkin, memberikan stimulasi atau rehabilitasi perkembangan bagi penderita gizi buruk masa lalu dalam rangka pencegahan cacat fisik maupun mental, intervensi PMT pada penderita gizi kurang dan gizi buruk terpadu dengan penanggulangan penyakit penyerta, serta pemantauan dan penanganan serius pada $46 \%$ balita KEP di Kabupaten Tanggamus oleh sektor terkait.

\section{Ucapan terima kasih}

Penulis mengucapkan terima kasih kepada Dr. Amirsyah, M.Kes selaku kepala dinas kesehatan dan staf yang telah memberikan kemudahan dalam penelitian ini, direktur RS Pringsewu dan staf khususnya dr. Agung Mudapati, Sp.A. yang telah banyak memberikan informasi dalam penelitian ini, seluruh kepala puskesmas seKabupaten Tanggamus dan petugas gizi yang ikut langsung dalam pengumpulan data di lapangan.

5. Suandi, I Kompiang Gede. Efek Kurang Energi Protein (KEP) terhadap Struktur Fungsi Organ, Metabolisme, dan Fungsi Hormon Endoktrin. Denpasar: Kanwil Kesehatan Provinsi Bali; 1999.

6. Prawirohartono EP. Status Gizi. Yogyakarta: Pusat Informasi Makanan Sehat (PIMS); 1997.

7. Widayani, Sus Syarif H, dan Clara MK. Hubungan antara Pola Asuh dengan Status Gizi Anak Batita pada Rumah Tangga Petani di Kabupaten Bogor. Media Gizi dan Keluarga 2001;XXV (2):73-82.

8. Supariasa IDN, Bakri B, Fajar I. Penilaian Status Gizi. Jakarta: Buku Kedokteran EGC; 2002.

9. Soekirman. IImu Gizi dan Aplikasinya untuk Keluarga dan Masyarakat. Jakarta: Dirjen Dikti Depdiknas; 2000.

10. Hartiningsih M, Aristiarini A. Seandainya Aku Bukan Anakmu (Potret Kehidupan Anak Indonesia). Kompas 2000. p. 8-19. 